\title{
Polysèmes
}

Revue d'études intertextuelles et intermédiales

\section{Mediation and the dream of the unmediated in D.H. Lawrence's short stories and poems}

\section{Paul Volsik}

\section{(2) OpenEdition}

\section{Journals}

\section{Electronic version}

URL: http://journals.openedition.org/polysemes/675

DOI: $10.4000 /$ polysemes. 675

ISSN: 2496-4212

\section{Publisher}

SAIT

\section{Printed version}

Date of publication: 1 January 2012

Number of pages: 155-179

ISSN: 0999-4203

\section{Electronic reference}

Paul Volsik, « Mediation and the dream of the unmediated in D.H. Lawrence's short stories and poems ", Polysèmes [Online], 12 | 2012, Online since 01 March 2015, connection on 02 May 2019. URL: http://journals.openedition.org/polysemes/675; DOI : 10.4000/polysemes.675

This text was automatically generated on 2 May 2019.

Polysèmes 


\title{
Mediation and the dream of the unmediated in D.H. Lawrence's short stories and poems
}

\author{
Paul Volsik
}

1 I would like to distinguish what I am attempting to do here from the traditional use of the word "transposition". Julia Kristeva, it will be remembered, uses the term for the introduction of an element from one sign system into another, here one genre to another. Any transposition by definition modifies the host-system. Collage would be a simple example of this, as would the juxtaposition, in the same textual space, of poems and short stories, as in Ted Hughes' Wodwo. This article will slightly enlarge the thrust of this definition, to examine how the "same" or at least an "analogous" ideological and aesthetic project (an attempt to reduce as far as possible all that mediates between man and himself, man and woman, man and the world, the writer or reader and text) can, when deployed or transposed in two different generic systems, find itself confronted with different resistances, provoking different turbulences, and imposing "generic" modifications or at least choices. And, it will be argued, it is precisely because of the historically determined priorities of each genre, and the way these are reciprocally defined, that an author can find himself wishing to deploy different aspects of the "same" thematic in different genres.

One could begin by restating what might seem to be obvious: that no human creation is or can be "unmediated", especially any object created out of a natural language. If one of the standard definitions of the word "mediation" is "a medium of transmission", the natural language English, which is the medium out of which Lawrence's work was largely made, constantly mediates between the speaker or reader and the world or text. To take just one linguistic example: the "meaning" of a word is of course plastic, its notional heartland reworked and remapped constantly, even for the most apparently "objective" word. One might take as an example the word "blue" which is at the heart of "Bavarian Gentians". 
Bavarian Gentians

Not every man has gentians in his house

in soft September, at slow, sad Michaelmas.

Bavarian gentians, big and dark, only dark

darkening the day-time, torch-like with the smoking blueness of

Pluto's gloom,

ribbed and torch-like, with their blaze of darkness spread blue

down flattening into points, flattened under the sweep of white day

torch-flower of the blue-smoking darkness, Pluto's dark-blue daze,

black lamps from the halls of Dis, burning dark blue,

giving off darkness, blue darkness, as Demeter's pale lamps give off

light,

lead me then, lead me the way.

Reach me a gentian, give me a torch!

let me guide myself with the blue, forked torch of this flower

down the darker and darker stairs, where blue is darkened on

blueness

even where Persephone goes, just now, from the frosted September

to the sightless realm where darkness is awake upon the dark

and Persephone herself is but a voice

or a darkness invisible enfolded in the deeper dark

of the arms Plutonic, and pierced with the passion of dense gloom,

among the splendour of torches of darkness, shedding darkness

on the lost bride and her groom. ${ }^{1}$

3 The word "blue" might here seem to be a purely "technical" term used to describe, as the dictionaries say, a colour that is formed by "radiant energy of the wavelength 475 millimicrons", and more particularly a specific type of gentian (the Bavarian as opposed, for example, to the Alpine). Linguists, however, constantly remind us that "blue" is an example of the constitutive complexity of the relationship between word and world in that Welsh (like Breton), to take the canonical example, can use the same word - "glas" for blue or green grey, thus refusing to make a distinction, to draw frontiers, in the way that English and French do. More pertinently, even, this colour has a history. Michel Pastoureau reminds us in his stimulating Bleu: Histoire d'une couleur, that we do not see colours in an unmediated way: "c'est la société qui 'fait' la couleur, qui lui donne sa définition et son sens, qui construit ses codes et ses valeurs, qui organise ses pratiques et détermine ses enjeux". ${ }^{2}$ Thus the effects of the aesthetic revolution of Romanticism (with its very particular relationship to the colour) are to be found in much early twentiethcentury discourse in its use of the colour blue, something of which Lawrence, as an inheritor of many Romantic topoi and priorities (including the very Keatsian "dissolutive" strategy of this particular poem) would be a good case in point. One could offer as an example, chosen because it comes from the same "spiritualist" intellectual current as Lawrence, and thus could be used to read this particular poem itself, particularly its double outward and inward movement, Lawrence's near-contemporary Kandinsky. Kandinsky in Du Spirituel dans l'art et dans la peinture en particulier (1909 - one year before his creation of the first "abstract" painting) writes thus of the colour:

Cette capacité d'approfondissement se trouve dans le bleu et déjà d'une manière

théorique dans ses mouvements physiques.

1) s'éloignant de l'homme et

2) vers son propre centre. 
Il en est de même si on laisse le bleu (sous une forme géométrique quelconque) agir sur l'âme. La puissance d'approfondissement du bleu est telle, qu'il devient plus intense justement dans les tons les plus profonds et qu'intérieurement, son effet devient plus caractéristique. Plus le bleu est profond, plus il attire l'homme vers l'infini et éveille en lui la nostalgie du Pur et de l'ultime suprasensible. [...] Le bleu développe très profondément l'élément du calme. Glissant vers le noir, il prend la consonance d'une tristesse inhumaine. Il devient un approfondissement infini dans des états graves qui n'ont pas de fin et qui ne peuvent en avoir. ${ }^{3}$

Kandinsky is unwittingly giving us a magnificent reading of "Bavarian Gentians" (for instance "tristesse inhumaine" as a definition of the absence of "pity" in the poem); but above all, like many artists (Lawrence too does this) he is attempting here to dehistoricise and "metaphysisise" his medium. That this strategy is intellectually problematic does not alter what interests us here about it: that it is with the help of such thinking that an aesthetic revolution occurred. It is not just that individuals see and sometimes choose to see colours differently (Lawrence is probably darkening his Gentians) and that history proposes certain configurations (both linguistic and generic) but that within, and in some sense thanks to these linguistic and generic configurations, writers can break new ground, transform the medium. It could be suggested that this is true of Lawrence in his poetry.

It is to explore this hypothesis that this article will proceed as follows: it will firstly define more clearly what is meant by the absence of mediation and justify the corpus; it will propose a brief and summary map of the dialogue between the short story and poetry (presented here in something of the opposition between English and Welsh in the period we are looking at); and finally it will work from Bakhtin's famous opposition between the dialogic and the monologic (an opposition which has always been problematic for specialists of poetry), to look comparatively at three textual phenomena: 1) the short story as a space of dialogue and, as prose work, a space of the dialogic; 2) Lawrence's construction of a particular lyric "I" and irony; 3) Lawrence's construction of the why of free verse.

Lawrence's thought is complex and unstable and we do not have time here to enter into the details of its progression. But what I would like to start from is his early poem "Manifesto" which, like all manifestoes, and paratexts, gives access to only part of the work itself and even then not in a totally reliable way. In it he presents a model of relationship between man and woman (an emblematic Lawrentian binary) as a double movement - and the word movement is important, picking up many aspects reflected in his work, such as the quest motif, or cumulative stylistic devices. This relationship involves firstly a personal liberation (here on the part of an I / male), an access to "pure existence, real liberty", the poem claiming that "It is in pure, unutterable resolvedness, distinction of being, that one is free". It is this state of "resolvedness" which I interpret as a resolution that permits the confrontation with the "terrible other". It is when the woman recognises that he is the "terrible other" (and vice versa) that the freed man creates the possibility of a radically freed space:

then I shall be glad, I shall not be confused with her, I shall be cleared, distinct, single as if burnished in silver, Having no adherence, no adhesion anywhere, One clear, burnished, isolated being, unique, And she also, pure, isolated, complete, Two of us, unutterably distinguished and in unutterable conjunction. 
Then we shall be free, freer than angels, ah perfect

[....] Having no laws but the laws of our own being

Every human being will then be like a flower,

untrammelled.

Every movement will be direct.

[...] We shall be, now,

We shall know in full.

We, the mystic NOW. ${ }^{4}$

7 The recurrence of the word "unutterable" in the text suggests what the reader feels, and feels only too often with Lawrence, that when he assumes this type of prophetic voice, he is - precisely - trammelled. For this text raises constant problems. Aesthetically the poem is extremely prosaic, lacks, for example, the sort of magnificent rhythmic "presence" which "Bavarian Gentians" has, and thus also manifestly lacks the very "vitality" that it programmatically calls for. It is also problematic intellectually in so far as, to my eyes at least, it deploys its paradoxes too easily: repeating ideas and not discovering them, it is "pedagogical" in the worst sense, the sense that Lawrence works in when he is least energised. Be that as it may, what interests me here is the simile "like a flower" - the Bavarian gentian being one avatar of this - though there are other topoi which carry this thematic in Lawrence's work, like for instance that of the flame. Being "like a flower, untrammelled" manifests and symbolises, for Lawrence, a direct mode of being and, above all, of understanding (one recognizes here the Romantic, Blakean inheritance, or Novalis' "fleur bleue"). For my corpus I have consequently chosen two texts which are the negative of each other: one poem, "Bavarian Gentians", which contains a "successful" encounter, and one short story, "Odour of Chrysanthemums", which is constructed around a failed encounter. Their titles suggest that these texts are using flowers as pivotal symbols of the "mystical" state of distinction / conjunction - what Lawrence sees (hence the title of this article) as the perfect "now" of the untrammelled, that which is not caught in the nets of shame and fear, not hobbled by the mind and its alienating productions.

"Odour of Chrysanthemums", it will be remembered, tells the story of a woman (we first encounter her as "a woman", only learning her name much later) who is angrily waiting for her husband to return from work or - as she is convinced - from the pub (we are here in the short story at its most "realist", or novelistic in some ways, avoiding the more rare, more exclusively epiphanic short stories). She later learns that he is in fact dead, suffocated in a pitfall. With his mother she prepares his body in a very striking sequence where, touching the dead body, she has the revelation of the full extent of the "shameful" wreckage and failure of their agonistic couple - notably a sexuality that had produced children but no real union. The story ends with two typically Lawrentian sentences, the narrator remarking, as she is tidying the kitchen: "She knew she submitted to life, which was her immediate master. But from death, her ultimate master, she winced with fear and shame". Taken out of context these sentences may sound somewhat heavy-handed as a closural procedure but they are in fact probably - though one may question this "earned" by what precedes. The choice of this short story enables me - in a necessarily simplifying way - to oppose two texts which deal with two encounters marked by a sexuality that is articulated with death or a death which is articulated with sexuality: one a poem that presents an "I" that does not "wince with fear and shame" as it confronts, in the moment of the now, these two overlapping dark spaces; the other, a short story that 
focuses on a "she" that has refused the "terrible otherness" of her husband (including his class and its culture) and whose discovery is "delayed" by both circumstance and text. But what interests us more than this thematic - with which one may feel more or less sympathy - are the generic constraints at work in the transposition of the theme from short story to poem.

The aesthetic and theoretical problem raised by great prose writers who are also great poets (Hardy is another striking example) is what exactly motivates the choice of one genre rather than the other at particular moments or for particular configurations. Lawrence we know as primarily a novelist and one who, though he was sometimes uncertain about the relative merits of the two genres (novel / poetry), most frequently stated that he valued the novel more highly. I will give just two of his statements on this from a text called "The Novel":

The novel is a great discovery: far greater than Galileo's telescope or somebody else's wireless. The novel is the highest form of human expression so far attained. Why? Because it is incapable of the absolute. ${ }^{5}$

You can fool pretty nearly every other medium. You can make a poem pietistic, and still it will be a poem [...] Now in a novel there's always a tom-cat, a black tom-cat that pounces on the white dove of the Word, if the dove doesn't watch it. ${ }^{6}$

Before analyzing the implications of these remarks, it is perhaps wise to recall, as a word of warning, that what we are faced with here is a historical problem. I would not wish in any way to defend or present these ideas as absolute, a-historical generic definitions. What they tell us is how Lawrence maps generic frontiers or generic ideals in a particular historical context of which he is the product and in which he is an agent. We could complicate this by remarking that the short-story occupies a third generic place which is very specific, constantly moving laterally between the binaries of novel and poem, binaries that are themselves constantly in flux.

11 It should be stressed that what we are witnessing in this is a complex process of reciprocal definition (of which I am here interested in only the aesthetic and not the admittedly important - economic dimension), which is constantly modified, as, within each genre, spaces are opened or closed (as Lawrence, for example, moves from rhymed to unrhymed poetry and back again and defines himself conflictually with other "canonical" short-story writers such as Poe, Hawthorne, Maupassant, James or Turgenev). Nevertheless I would like to underline the fact that Lawrence here compares the novel with two means of transmission, moving in two different directions - light and sound and that his paradoxical conclusion is that the novel is (fortunately, he argues) totally incapable of rendering the mystical state where all mediations are abolished and

Every movement will be direct.

[...] We shall be, now,

We shall know in full.

We, the mystic NOW.

12 If one wished to translate Lawrence's wonderfully precise metaphorical remarks about the novel into the more theoretically better-known ones of his near contemporary Bakhtin to draw attention to the opposition between the monologic and the dialogic, then like Bakhtin, it could be argued, Lawrence seems to see the novel as the genre inescapably grounded in the conflictual, the dialogic, sees it as a genre that does not and, fortunately, cannot give access to the monologic, the absolute or the "pietistic", in that the darker "male" forces of the black-tomcat literally or literarily put the cat among the doves 
("purer than the angels", incarnations of a holier spirit and the divine logos - thus perhaps feminine) which are just waiting to fly back into the... blue (Mary's colour of course) spaces.

To return to Bakhtin, whose definition - though this is not a major problem in this perspective - has always, it is worth recalling, been seen as problematic by poetry specialists in that it is grounded in a historically determined (largely late Romantic and lyrical) definition of the essence of poetry, I would like to quote one extract from his seminal Esthétique et théorie du roman in which he explains how the novel, unlike poetry, is characterised by internal conflicts (the struggle between black cat and white dove) which he calls the dialogical. To quote Bakhtin:

Dans la représentation poétique au sens strict du terme (dans l'image-trope), toute l'action (la dynamique mot-image) se joue entre le mot et l'objet (sous tous leurs aspects). Le mot se coule dans la richesse inépuisable, dans la multiformité contradictoire de l'objet lui-même, dans sa nature encore "vierge » et " inexplorée » [...]. Pour l'artiste prosateur, au contraire, l'objet révèle avant tout la multiformité sociale plurilingue de ses noms, définitions et appréciations. Au lieu de la plénitude inépuisable de l'objet lui-même, le prosateur découvre la multitude de chemins, routes, sentiers, tracés en lui par sa conscience sociale [...]. Pour le prosateur, l'objet est le point de convergence de voix diverses, au milieu desquelles sa voix aussi doit retentir. ${ }^{7}$

This leads us back, then, to our flowers. In Bakhtin's analysis, which, I would suggest, applies very well to the type of poem that "Bavarian Gentians" represents, the poet is attempting to explore the "multiformité contradictoire de l'objet lui-même, dans sa nature encore 'vierge' et 'inexplorée"' whereas in "Odour of Chrysanthemums" (and the switch from flower to an "odour" which is smelt by different human beings is perhaps a sign) "l'objet est le point de convergence de voix diverses, au milieu desquelles sa voix aussi doit retentir".

To attempt to prove this point, to attempt to show how genres can "help" or "resist" the same thematic concern, I will - to repeat myself - look briefly and successively at 1) the short story as a space of dialogue and the dialogic; 2) Lawrence's construction of a particular lyric "I" and its compatibility with irony; 3) Lawrence's understanding of free verse as the absolute space in which as many mediations as possible are abolished and the dialogic replaced by the monologic.

The short story (or rather this short story) is, I would suggest, a space of dialogue not only in the Bakhtinian sense but also in the perhaps not so trivial original sense of being a space where characters dialogue (something which is of course not true of all short stories). If one explores this apparently banal statement, one might like to insist on two things: firstly, dialogue is a dialogue between several "I"s - what are traditionally called characters and narrator, where these speak not only from different points of view but also in different "languages". As for characters, however one defines this notoriously difficult category, and attempting to avoid naïve psychological definitions and confusions between "real" human beings and the "beings" or "effects" generated by, in Valéry's much quoted words, those "vivants sans entrailles" that help construct novels and short stories, it would seem that narratologists are constantly drawn back to the existence of character as one of the defining characteristics of prose (novel or short story) as a genre as something, at least, which radically distinguishes it from poetry. Vincent Jouve, for example, suggests in his L'Effet personnage dans le roman: 
Le personnage de roman se caractérise en effet par son appartenance à un écrit en prose (se distinguant par là du personnage de théâtre qui ne s'accomplit, lui, que dans la représentation scénique), assez long (ce qui lui donne de l'« épaisseur » que ne peuvent avoir les acteurs de textes plus courts comme le poème ou la fable), et axé sur une représentation de la «psychologie » (à l'inverse, donc, de récits plus « événementiels » comme le conte ou la nouvelle). ${ }^{8}$

This definition is in some ways problematic in that recalling that the idea that the short story is necessarily "événementielle" or that a decisive criterion of generic definition is the question of "length" immediately raises the problem of "long poems" such as "Beowulf", "The Canterbury Tales", "The Fairy Queen", "Paradise Lost", "Peter Bell", "Andrea del Sarto", "The Waste Land", etc., which contain "characters" who do develop. Nevertheless it would seem to be a given that narratologists, or at least the majority of them, seem impelled to link the category of character to that of "intrigue", seen as another defining characteristic of the novel - and often seen as a defining characteristic of the short story. We find this famously in Henry James' controversial, but much quoted, aphorism in "The Art of Fiction" (1884): "What is character but the determination of incident? What is incident but the illustration of character?" However much one might wish to question this sort of definition, the fact that character is distinct from narrator as narrator is from author, means that the reader, whose constant task is to "determine", in James' word, meanings and articulations, is constantly in a position to "relativize" statements made by characters in a way that is more difficult in the sort of text that "Bavarian Gentians" represents.

How does this manifest itself in "Odour of Chrysanthemums"? In several ways. Firstly, and obviously, the characters (who constitute nodes in a complex network of social relationships mother / child, woman / woman, / women) speak in dialect, unlike the narrator whose English is generally standard - though not always since he occasionally uses dialect words like "butty" (a middleman negotiating between a mine owner and the miners). He is thus (if only in a "class" or "regional" sense) not a purely neutral narrator, manifesting a certain closeness to the male miners. Moreover the degree of dialect used by characters is one of the ways in which the reader constructs the complex social and hence ideological network that, at one level, informs the short story. The "heroine", Elizabeth Bates, uses less dialect than the miners (and hence, one presumes, her silent husband) and thus, in her desire for linguistic "order", articulates the problem of the orders of sexual behaviour with that of the social against a typically Lawrentian scale constructed by Romanticism where the more dialectal the language the more "authentic" the experience, the more "native" the apperception, the more rooted in the physical, and the more physical... often the more male. Inversely, the more standardised the language the more it is seen as lacking in primary energies, as the language of the socially privileged is seen as "languishing", as Lawrence says of the Oxford voice in his poem on the subject. ${ }^{9}$ Where "Bavarian Gentians" takes place in the timeless space of "myth" (however much it is also rooted in Lawrence's biography and his negotiations with his coming death) in a totally standard English, "Odour of Chrysanthemums" takes place in an industrial space riven and driven by conflict - one of whose manifestations is syntax, the central problem of connection that haunts the story. Society and text are dis/ connected by the warring existence of multiple dialects.

More concretely still, it is interesting to see how the central topos of the "odour of chrysanthemums" (i.e. how the chrysanthemums are "read" by different characters) is deployed in the short story. Notably one could draw attention to the fact that at one 
moment the daughter smells the dying chrysanthemums which her mother had, at the beginning of the story, placed in her apron strings over her pregnant stomach (one sees here a traditional folk-motif) and says:

"Don't they smell beautiful!"

Her mother gave a short laugh.

"No," she said, "not to me. It was chrysanthemums when I married him, and chrysanthemums when you were born, and the first time they ever brought him home drunk, he'd got brown chrysanthemums in his button-hole."10

We have here a similar central topos to that of "Bavarian Gentians", a thematic continuity where birth and death, the possibility / impossibility of rebirth are associated with the presence of flowers, just as the space of Hades in the poem echoes the Chthonic galleries of the mine in the short story, or the torches of "Bavarian Gentians" the candle of "Odour of Chrysanthemums" - but with a major difference. In the short story there is a voice that says "no", there is dialogue, difference of point of view (daughter and mother contradict each other). In the poem there is no dialogue, no "characterized" voice that can say "no" to the reading of the flower proposed by the lyric "I". We are in a monologuing, if not largely monologic space in the poem, whereas we are in a dialogic space in the short story. More importantly the second occurrence of the chrysanthemums as flowers that smell (though the word "odour" is not used) occurs later in the short story where Elizabeth finds herself alone in the room in which the body of her husband is to be laid out. The narrator writes
She set down the candle and looked round. The candle-light glittered on the lustre- glasses, on the two vases that held some of the pink chrysanthemums, and on the dark mahogany. There was a cold, deathly smell of chrysanthemums in the room. Elizabeth stood looking at the flowers. She turned away, and calculated whether there would be room to lay him on the floor... ${ }^{11}$

The reader here, in so far as (s)he chooses to occupy the role of what Jouve calls the "lectant", i.e. the critical reader, and distances himself from the pathos (which he might feel as a "lisant"), has to do several things. He can first note that in the Victorian - and apparently still contemporary (according to Interflora) - English language of flowers, red chrysanthemums were a symbol of love, the pinkness of the flowers raising the problem of attenuation. But the reader has also to think through the problem of the "reality" of the smell of chrysanthemums: is this smell indeed "beautiful", is it deathly, is the beautiful deathly, the deathly beautiful etc.? In other words, the reader is forced to call up his own "encyclopaedia" - just as he has to for "lustre-glasses" which pointedly place the text socially. Moreover the reader has to interpret the difference between the exclamative enthusiasm of the daughter and the turning away of the mother: is Lawrence dialoguing several ages of womanhood - innocent daughter / experienced wife - as each negotiates with the complex values the chrysanthemums carry? What is important here is that we are not in the space of ambivalence (something one senses in "Bavarian Gentians"). Ambivalence can characterize any "I" (including Elizabeth Bates) or the "I" of "Bavarian Gentians". In this short story we are in the space of something more radical, where several distinct ambivalences enter into conflict.

But it is not just laterally, in the relationships between the characters, that the dialogic manifests itself. There is also the problem of tropes such as irony, which are also manners of opening up in the depth of the text a "multiformité des appréciations", to use Bakhtin's text. It is interesting to look again at the first quotation I gave from the short story and the fact that, when the mother replies to the daughter, she does so with a "short laugh". 
It is a characteristic of this story that declarative verbs form a constant counterpoint. Where the men are "cheery" or "hearty", Elizabeth's utterances are constantly qualified by adverbs like "sternly", "bitterly" ("she laughed bitterly"), "irritably", "in a tone of fine bitter carelessness", etc. With such a massive density (and repetition is one of the stylistic characteristics that enables one to recognize the family relationship between poem and short story), it would seem difficult not to interpret the laugh on this occurrence as a form of bitter irony, the form of irony - sarcasm - with which Lawrence was most at ease as one sees in his rhymed poems. Could the reader find such irony in the chronology of the failure of the marriage, from upright beginning to collapse, from church to pub, with the possibility that the husband's placing of the dead chrysanthemum in his own button hole was itself an ironic gesture, a yellow chrysanthemum symbolising slighted love in the language of flowers, the brown, then, perhaps a dead love - combined with the husband's own possible irony about the joys of sociability and the "suicidal" choice of drunkenness? If one may be allowed this "ironic" interpretation I would like to envisage the possibility of a generic distinction (for Lawrence at least) in the centrality and even possibility of the articulation between the lyric voice (as he understood it) and irony given that irony is traditionally seen by theoreticians of the genre, such as Shaw and Tibi, to be a characteristic generic strategy of the short story.

Philippe Hamon, the narratologist, whose book on irony I find one of the most stimulating, examines in an interesting article on "Le sujet lyrique et l'ironie", after a fine passage where he dismisses the whole notion of "sujet lyrique", the "effet de sujet" one finds in certain forms of lyric poetry and proposes three characteristics that could constitute the beginnings of a cahier des charges which would be genre-specific. The first is the impression of "orality" one finds in lyric poetry. This manifests itself, for example, in the exclamation mark at the end of the first line of the poem, or by vocative forms like the lyric "ô", not quite the "oh!" of real speech, the "ah!" of Lawrence's "Manifesto". Interestingly enough, in this respect, in the manuscripts of "Bavarian Gentians", when Lawrence suddenly realized that the myth of Penelope and Pluto was the right intertext, the mythic objective correlative, he wrote in pencil

Oh, I know -

Persephone has just gone back

This juxtaposition of "Oh" and "I" of course strongly induces the presence of a speaking "I" (as direct speech does in a short story) but its imperious presence attempts to exclude all other voices. This, in Hamon's eyes, is linked to a certain nostalgia (and I would personally take the word nostalgia in the sense of yearning for the future) for a performative functioning of language, the moment when "dire, faire et être sont indissociables". This dream of indissociability also haunts one face, one model of the possibility of the unmediated and of lyricism - the dream of a fundamental recentring, where the "je" would not be "un autre", as we know, of course, (s)he is in the matter of textuality, and the real world would be an incarnation of "intensity" -, the high monologic of Bakhtin's model. The poet in this configuration becomes "un voyant". Such is Joyce Carol Oates' reading of Lawrence as visionary (in New Heaven New Earth), or Sandra M. Gilbert's grounding of his achievement in "acts of attention" whose paternity goes back, for her, through Pater to Coleridge, acts of attention that Lawrence himself saw as foundational for his poetry. "The essential quality of poetry is that it makes a new effort of attention, and 'discovers' a new world within the known world" (in his Preface to Harry Crosby's "Chariot of the Sun"12). 

in his "Manifesto", it was the essential and radical otherness of the object, attended to intensively, that he was most apt to render, something which struck a poet with whom he has nothing in common, W.H. Auden, when he writes, talking of a Lawrence poem about a she-goat, "In passages like these, Lawrence's writing is so transparent that one forgets him entirely, and simply sees what he saw"13, an impression which V. de Sola Pinto in some sense canonised when he entitled his introduction to the Complete Poems "D.H. Lawrence: Poet without a Mask". It is this apparent absence of mask or "persona", this impression of a direct exploratory interaction between a "sujet lyrique" and the world, that I understand by the dream of the absence of mediation, a dream, an "effet" which Lawrence had the skill to make possible for us by his use of identifiable textual devices, rhythm being the most obvious, hypnotic parallelisms and repetition of elements that are often not, in themselves, interesting, another. Here again the ideal is not perfectly incarnated in the text, in that, for example, the use of intertext (the myth) itself inevitably creates distance in "Bavarian Gentians".

Nevertheless the poem is saturated with devices that generate an impression of presence - be it only the basic choice of tense and mode such as the imperative. Nevertheless Hamon raises an interesting question: is irony compatible with this type of lyric "I"? is the desire to create this type of transparent voice compatible with irony? No, says a certain doxa. Hamon quotes, for example, Verlaine: “Ta parole est morte de l'argot et du ricanement" ("Sagesse"), (raising in a sense, or perhaps in addition, the problem of the combined presence of irony and dialect) - and Lautréamont: "La poésie se trouve partout où n'est pas le sourire stupidement railleur de l'homme à la figure de canard." ${ }^{14}$ This hypothesis, that a certain type of lyric "I" knows nothing of irony, though one would have to tread carefully about the notion of the lyric and be more precise about various types of irony (distinguishing, for example, Romantic Irony from other forms), probably does suggest something about the type of text of which "Bavarian Gentians" is an example, texts, that is, which, at a very basic level, are not fractured, "saying one thing to mean another", which do not presuppose a fractured readership (those who perceive and understand the irony and those who do not). And this would make sense of another fundamental characteristic of Lawrence's poetry - its belatedness. For irony is precisely one of the characteristics of the Modernist poetry that grows out of Baudelaire, who wrote famously: "Ne suis-je pas un faux accord / Dans la divine symphonie / Grâce à la divine ironie / Qui me secoue et me mord" 15 as it will bite into Prufrock and his likes, irremediably creating a gulf between them and the world, and help constitute Modernism's fundamental new articulation (in I.A. Richards, for example) of irony and the poetic text. But more particularly in relation to our corpus it is worth noting that what Lawrence does do in "Odour of Chrysanthemums" and does not do in "Bavarian Gentians", is precisely deploy irony. In the short story this appears as an irony about a "mechanized" industrial world and a repressive mindscape that prevents human beings from achieving the sort of visionary encounter that "Manifesto" talks about - the sort of irony that is deployed in the opening paragraph's juxtaposition of the industrial and the natural which both "explains" and provides a frame for the "disillusionment" 16 that the woman feels, as it does for the parlous state of the chrysanthemums.

But there is one final, and perhaps central, difference between Lawrence's short stories and his poetry and that is that his poetry is formally more radical than his short stories. Whereas formally (if not thematically) histories of the short story do not see Lawrence as 
a radical figure in the genre (though one greatly admired by major writers in the United States - Sherwood Anderson or Joyce Carol Oates or Eudora Welty), in poetry he is indeed aesthetically radical, at least in a British context, in his instinctive grasp of the importance of Whitman's breakthrough with free verse, and his ability to transform this theoretical understanding into text. It could be argued that what we appreciate in Lawrence's short stories (this is inexcusably impressionistic) is the same "rough hewn" quality, the same sense of an amazing, spur-of-the-moment, "off-handedness" in the etymological sense that one finds both in Lawrence's free verse and in the construction of his best short-stories. Lawrence is at his best - perhaps - when he is off-handed in the sense that he is not "hands on", not apparently wanting to master the text, when he is letting the black cat move to its own ends, and with eyes dilated, among the white doves.

The locus classicus of Lawrence's theory of free verse, whose origins lie in his complex, and as always extremely conflictual, dialogue with Whitman, the Imagists and the Futurists, is his famous 1918 preface to the American edition of New Poems. This deserves a detailed analysis, even in its use of the word "blue". I would, here, simply like to quote one famous passage where, opposing fixed forms to free verse, Lawrence writes:

The poetry of the beginning and the poetry of the end must have that exquisite finality, perfection which belongs to all that is far off. It is the realm of all that is perfect. It is the nature of all that is complete and consummate... these are the treasured gem-like lyrics of Shelley and Keats.

But there is another kind of poetry: the poetry of that which is at hand: the immediate present. In the immediate present there is no perfection, no consummation, nothing finished. The strands are all flying, quivering, intermingling into the web, the waters are shaking the moon. There is no round, consummate moon on the face of running water, nor on the face of the unfinished tide... Life, the ever-present, knows no finality, no finished crystallisation. The perfect rose is only a running flame, emerging and flowing off, and never in any sense at rest, static, finished. Herein lies its transcendent loveliness. ${ }^{17}$

To conclude - and faced with a text like this - we could don the mask of Lautréamont's "homme à la figure de canard" and show the impossibility and contradictions of this stance. In some senses what Lawrence is describing here is as much his vision of the novel as of a certain form of poetry. Lawrence's theme, it should be stressed, does not require free verse: many of his Romantic forebears, who are nowhere near as "gemlike" as he suggests, and some of his contemporaries, including Dylan Thomas, explored a similar territory without recourse to the form. Inversely free verse can and has been used to totally other thematic ends (one thinks of Cummings or Pound). Lawrence's expressed yearning for a "transcendence" that in other texts he claims the novel and free verse fortunately can never achieve is a classic example of contradiction. Lawrence contradicts himself, but to quote his mentor Whitman: "I contradict myself? So, I contradict myself, I am large, I contain multitudes". ${ }^{18}$ And it is this notion of contra/diction, including that between a certain construction of a certain type of prose work and a certain type of poetry, this letting the generic multitudes speak in his work, his letters, his stories, his travel writing, his novels, opening up a territory that will also produce a whole series of extraordinary poems in which, against the odds and the nature of the medium itself, the reader can and does have the impression (and I would insist on the word) that "presence" is possible, that we are witnessing what for Lawrence was the justification of free verse: "direct utterance from the instant whole man" 19 , a certain access to the physical and creative quick and the metaphysical absolute. It is this that marks a unique achievement of D.H. Lawrence. 


\section{BIBLIOGRAPHY}

Auden, W.H. The Dyer's Hand and other Essays. London: Faber \& Faber, 1975.

Bakhtine, Mikhaill. Esthétique et théorie du roman. Paris : Gallimard, coll. Tel, 1978.

Gilbert, Sandra M. Acts of Attention. The Poems of D.H. Lawrence. Ithaca, London: Cornell UP, 1972.

Hamon, Philippe. L'Ironie littéraire: essai sur les formes de l'écriture oblique. Paris: Hachette supérieur, 1996.

Jouve, Vincent. L'Effet-personnage dans le roman. Paris : PUF, 1992.

Kandinsky, Wassily. Du Spirituel dans l'art, et dans la peinture en particulier. Paris : Denoel, 1989.

Lawrence, D.H. The Complete Poems of D.H. Lawrence. New York: The Viking Press, 1971.

Lawrence, D.H. The Prussian Officer. Harmondsworth: Penguin, 1986.

Lawrence, D.H. A Study of Thomas Hardy and other Essays. Cambridge: CUP, 1988.

Pastoureau, Michel. Bleu: histoire d'une couleur. Paris : Seuil, 2000.

\section{NOTES}

1. D.H. Lawrence, The Complete Poems of D.H. Lawrence, New York: The Viking Press, 1971, 697.

2. Michel Pastoureau, Bleu : histoire d'une couleur, Paris : Seuil, 2000, 9.

3. Wassily Kandinsky, Du Spirituel dans l'art, et dans la peinture en particulier, Paris: Denoel, 1989, 149-150.

4. Lawrence, Complete Poems, op. cit., 267-268.

5. D.H. Lawrence, A Study of Thomas Hardy and other Essays, Cambridge: CUP, 1988, 179.

6. Ibid., 181.

7. Mikhaïl Bakhtine, Esthétique et théorie du roman, Paris : Gallimard, coll. Tel, 1978, 101-102.

8. Vincent Jouve, L'Effet-personnage dans le roman, Paris : PUF, 1992, 22.

9. Lawrence, Complete Poems, op. cit., 433.

10. D.H. Lawrence, The Prussian Officer, Harmondsworth: Penguin, 1986, 210.

11. Ibid., 218.

12. Sandra M. Gilbert, Acts of Attention. The Poems of D. H. Lawrence, Ithaca, London: Cornell UP, 1972, 3.

13. W.H. Auden, The Dyer's Hand and Other Essays, London: Faber \& Faber, 1975, 292.

14. Maldoror, sixième chant.

15. XXIX "Le Vampire".

16. D.H. Lawrence, A Study of Thomas Hardy, op. cit., 205.

17. D.H. Lawrence, Complete Poems, op. cit., 181-182.

18. "Song of Myself", section 50, 1l. $1324 \mathrm{ff}$.

19. D.H. Lawrence, A Study of Thomas Hardy, op. cit., 184. 
INDEX

oeuvrecitee Odour of Chrysanthemums, Bavarian Gentians 